\title{
The Impact of Strategic Human Resource Management on Organizational Innovation and Knowledge Management Capacity (Case Study of Saipasitruen Company)
}

\author{
Susan Boostani ${ }^{1}$, Ali Sabbaghian ${ }^{2 *}$ \\ ${ }^{1,2}$ Department of Management, Naragh Branch, Islamic Azad University, Naragh, Iran \\ *Corresponding Author: asabbaghian@iau-naragh.ac.ir
}

\begin{abstract}
The purpose of this research is to investigate the effect of strategic human resource management on organizational innovation and knowledge management capacity (Case Study of Saipakitruen Company). The research method is descriptive-survey. The statistical population consisted of all staff members of Saipatiroun (2884 people) who were selected by simple random sampling of 340 people using the Morgan table. Data gathering tools include Human resources management Strategic Management Inventory, Organizational Innovation, Knowledge Management Capacity Ogger Yuzgat et al. (2015). Data analysis was performed using structural equation modeling method. Findings of the research showed that HRM has an impact on the components of knowledge management capacity (knowledge acquisition, knowledge sharing, knowledge software, exploration and exploitation) (P<0.05). The results showed that strategic human resource activities of organizations positively affect organizational innovation $(\mathrm{P}<0.05)$. Organizational HRM positively affects organizational organizational knowledge management capacity $(\mathrm{P}>0.05)$.
\end{abstract}

Keywords: Strategic Human Resource Management, Organizational Innovation, Knowledge Management Capacity, Staff

\section{Introduction}

Nowadays, there is a general agreement on the importance of the growing innovation in the organization and the market's more dynamic. Organizations need to innovate to respond to their customer's changing demand and lifestyles, as well as to take advantage of opportunities created by technology and market changes ( Rollie, 2011).

Dynamic and non-dynamic sets of today's businesses make companies move to innovation. In particular, companies must take part in a variety of innovation activities in order to increase their competitive advantage and lead to longterm survival. Exploring and exploiting a variety of innovations attracted the attention of many people in the field of literature. Previous research found that organizational innovation was related to firm performance, corporate strategic targeting, productivity, and organizational culture. In addition to studying the level of organization that explored exploration and exploitation, recent studies have emphasized the team and individual level of innovation. Innovation has increasingly become one of the long-term success factors of companies in competitive markets, as high-capacity companies will be able to respond more quickly and more effectively to environmental challenges (Jimens, 2008). Therefore, innovation plays an important role in creating value and maintaining competitive advantage. The main concept of innovation literature is a variety of innovations. Among the massive models, frameworks, classifications and definitions of innovation, it is difficult to understand the various types of innovation and the relationship between them (Rollie, 2011). Depending on the applications and levels studied, innovation has been differentiated into different types. Usually, researchers believe that they understand the concept of the process of innovation.

Successful executives now believe that valuable assets that give us competitive advantage are our employees and are the only ones that keep us in the lead of competition. Organizations today have become aware of the potential and emerging potential of human resource strategy and the growing and central role of intangible assets and intellectual capital (Becker, Hussielde and Ulrich, 2009). Most scholars also emphasize on the strategic management of human resources that the capabilities and activities of human resource management will lead to organizational innovation (Ramlal, 2006). Therefore, given the importance of companies that have successfully stabilized their position, they have a competitive advantage over competitors in the industry. On the other hand, companies that do not have a strong position in the industry are in difficulty with other companies and can not gain competitive advantage in this way (Rose and Kumar, 2006). 
Knowledge management has recently been introduced as a new discipline. Given its novelty, it is still likely to develop its theoretical origins (Darush, 2005). While accepting KM, it is disappointing to note that there is little guidance in the literature on what effective knowledge management really means or what quantitative results it can be. Perhaps this is due to the difficulty of identifying and measuring knowledge and knowledge management with the implication of a large part of knowledge and knowledge management components (Noaka and Tacouchi, 1995).

\section{Literature Review}

Zahira, Gurab, Karaboujk and Kold (2016), a research entitled Strategic human Resources Management and Company Performance: Mediating role of entrepreneurial orientation. For this purpose, a questionnaire was prepared and data was collected from companies operating in various industries in Istanbul. Data were analyzed by SPSS and AMOS. The results of the analyzes showed that the entrepreneurial orientation is a mediator between the relationship between strategic management of human resources and performance (financial performance and employees) of the company. Ferreira (2016) conducted a research on organizational innovation, re-purchasing, service cost, customer loyalty. With the chance of re-purchasing, how much will it tolerate against rising prices, with the assumption that there is no willingness to re-sell, the price reduction is to create a degree of willingness.

Ugur Yozgat et al. (2015), a research entitled The Impact of Strategic human Resources Management Impact on Organizational Innovation and Knowledge Management Capacity. The results of regression analysis emphasize that only specific activities in strategic human resources have the power to predict organizational innovation. In addition, a similar pattern was observed between strategic human resource activities and the company's knowledge management capacity. In general, our findings consider the importance of service compensation, training systems and performance evaluation as predictors of dependent variables.

Junali (2014), a research entitled Innovation by the organization Satisfaction from the comparison of service performance with customer expectations has provided satisfaction from the comparison of the product or service performance received with the customer's ideal product or service. The success of a post-sales organization's innovation is affected by the comparison of service performance with customer expectations, but the satisfaction of comparing the performance of the product or service received with the customer's product or service is not affected.

Taleghani et al. (2017), a research study on the impact of strategic Human Resources Management tools on improving organizational performance among Tehran University staff. The statistical population of this research is Tehran University staff. Using Cochran's formula, 384 people were selected as samples. The result of the analysis of hypotheses shows that: Strategic HR management tool has a positive and significant effect on organizational performance in Tehran University.

Ahmad Pour Dariyani (2016), a research entitled Identifying the Success Factors of Strategic Human Resource Management in Small Businesses. The statistical population of this research includes two groups of owners and managers of small and medium sized agricultural enterprises in Zanjan province. According to Cochran's formula, 196 managers and 208 small and medium business owners were selected using appropriate proportional sampling method to conduct research. The results of exploratory factor analysis and confirmatory factor analysis showed that the success factors of strategic HRM management in small and medium businesses are made up of five factors: support infrastructure, management, information technology, motivation and education.

Kamali Fahim (2016), a research on human resource management, focused on innovation through knowledge management capacities. The findings point to the fact that, although according to previous studies, human resource management capabilities have been influenced by knowledge management capacities on organizational innovation, Human resources management capabilities are not directly relevant to innovation.

Saleki (2016), A Survey on the Impact of Knowledge Management on Innovation at the Ministry of Oil Headquarters. The result of the research showed a positive and high correlation between all aspects of knowledge management and innovation so that all statistical assumptions were confirmed.

jahaniyan (2015) study has been conducted to investigate the relationship between intellectual capital and innovation and creativity of human resources in the organization. The existence of high intellectual capital leads to increased creativity and innovation of the organization's staff, and if the ground for creativity is provided, the process of organizational performance improves, and as much in this interaction of intellectual capital is low, the level of creativity and innovation decreases. 


\section{Methodology}

\subsection{Descriptive Statistics}

Descriptive statistics were used to examine the demographic characteristics of respondents. The frequency of respondents is based on gender, marital status, age, educational level, and related graphs.

Gender: 332 people mean $97.65 \%$ of respondents are male and 8 are female.

Table 1. Frequency distribution of respondents based on gender

\begin{tabular}{c|c|c|c}
\hline Gender & Frequency & Percent & Cumulative Frequency \\
\hline Man & 322 & 97.65 & 97.65 \\
\hline Female & 8 & 2.35 & 100.00 \\
\hline Total & 340 & 100.00 & \\
\hline
\end{tabular}

Marriage: 83 respondents are single and make up less than $25 \%$ of the sample size. There are 257 married respondents.

Table 2. Frequency of respondents by marriage

\begin{tabular}{c|c|c|c}
\hline Marital Status & Frequency & Percent & Cumulative Frequency \\
\hline Single & 83 & 24.41 & 24.41 \\
\hline Married & 257 & 75.59 & 100.00 \\
\hline Total & 340 & 100.00 & \\
\hline
\end{tabular}

Dgree of education: A total of 7 people have a diploma certificate. They have a college degree of 45, which represents $13.24 \%$ of the sample size. Individuals with a bachelor's degree of 196 persons and a person with a Master's degree and a doctoral degree of 92 persons.

Table 3. Frequency of respondents based on Education

\begin{tabular}{c|c|c|c}
\hline Education & Frequency & Percent & Cumulative Frequency \\
\hline Diploma certificate & 7 & 2.06 & 2.06 \\
\hline Assistant & 45 & 13.24 & 15.29 \\
\hline Expert & 196 & 57.65 & 72.94 \\
\hline Masters & 92 & 27.06 & \multirow{2}{*}{100.00} \\
\hline Total & 340 & 100.00 & \\
\hline
\end{tabular}

Age: 68 respondents aged 20 to 30 years old and $20.00 \%$ of sample size. There are 94 respondents aged 31 to 40 years old. 120 people are between 41 and 50 years of age, and 58 are over 50 .

Table 4. Frequency of respondents based on work experience

\begin{tabular}{c|c|c|c}
\hline Age & Frequency & Percent & Cumulative Frequency \\
\hline 20 to 30 years & 68 & 20.00 & 20.00 \\
\hline 31 to 40 years old & 94 & 27.65 & 47.65 \\
\hline 41 to 50 years & 120 & 35.29 & 82.94 \\
\hline More than 50 years & 58 & 17.06 & 100.00 \\
\hline Total & 340 & 100.00 & \\
\hline
\end{tabular}

\subsection{Descriptive analysis of research variables}

For descriptive analysis of the research variables, the central parameters (mean, median, and fashion) and dispersion parameters (standard deviation, variance and range of changes) were used according to the table. 
Table 5. Descriptive analysis of research variables

\begin{tabular}{lccccccccc}
\hline \multicolumn{1}{c}{ Variables } & Number & Average & Middle & Mode & $\begin{array}{c}\text { Standard } \\
\text { deviation }\end{array}$ & Variance & $\begin{array}{c}\text { Variation } \\
\text { range }\end{array}$ & Min & Max \\
\hline $\begin{array}{l}\text { Strategic } \\
\begin{array}{l}\text { Management of } \\
\text { Human Resources }\end{array}\end{array}$ & 340 & 3.501 & 3.500 & 4.000 & 0.800 & 0.641 & 3.167 & 1.667 & 4.833 \\
\hline earn knowledge & 340 & 3.861 & 4.000 & 4.000 & 0.746 & 0.556 & 4.000 & 1.000 & 5.000 \\
\hline share & 340 & 3.783 & 4.000 & 4.000 & 0.695 & 0.484 & 3.571 & 1.429 & 5.000 \\
\hline $\begin{array}{l}\text { Knowledge } \\
\text { Software }\end{array}$ & 340 & 3.548 & 3.600 & 3.600 & 0.675 & 0.456 & 3.600 & 1.400 & 5.000 \\
\hline $\begin{array}{l}\text { Exploration } \\
\text { utilization }\end{array}$ & 340 & 3.644 & 3.750 & 4.000 & 0.810 & 0.657 & 4.000 & 1.000 & 5.000 \\
\hline $\begin{array}{l}\text { Knowledge } \\
\begin{array}{l}\text { Management } \\
\text { Capacity }\end{array}\end{array}$ & 340 & 3.591 & 3.667 & 4.000 & 0.825 & 0.681 & 4.000 & 1.000 & 5.000 \\
\hline $\begin{array}{l}\text { Organizational } \\
\text { innovation }\end{array}$ & 340 & 3.758 & 4.000 & 4.000 & 0.760 & 0.577 & 3.333 & 1.667 & 5.000 \\
\hline
\end{tabular}

\subsection{Normal test data}

In this study, Kolmogorov-Smirnov test was used to test the normality of the data. For normal test data, statistical assumptions are set as follows:

H0: The distribution of data about variables is normal

H1: The distribution of variables is not normal

Table 6. Normality Test

\begin{tabular}{ccccccccc}
\hline & $\begin{array}{c}\text { Strategic } \\
\text { Management } \\
\text { of Human } \\
\text { Resources }\end{array}$ & $\begin{array}{c}\text { Earn } \\
\text { knowledge }\end{array}$ & Share & $\begin{array}{c}\text { Knowledge } \\
\text { Software }\end{array}$ & Exploration & Utilization & $\begin{array}{c}\text { Knowledge } \\
\text { Management } \\
\text { Capacity }\end{array}$ & $\begin{array}{c}\text { Organizational } \\
\text { innovation }\end{array}$ \\
\hline $\mathrm{N}$ & 340 & 340 & 340 & 340 & 340 & 340 & 340 & 340 \\
\hline Average & 3.501 & 3.861 & 3.783 & 3.548 & 3.644 & 3.591 & 3.758 & 3.444 \\
\hline $\begin{array}{c}\text { Standard } \\
\text { deviation }\end{array}$ & 0.800 & 0.746 & 0.695 & 0.675 & 0.810 & 0.825 & 0.760 & 0.739 \\
\hline Statistics ks & 1.151 & 3.206 & 1.961 & 0.930 & 2.243 & 2.294 & 1.924 & 1.909 \\
\hline $\begin{array}{c}\text { Significance } \\
\text { level }\end{array}$ & 0.114 & 0.056 & 0.165 & 0.131 & 0.169 & 0.123 & 0.097 & 0.093 \\
\hline
\end{tabular}

Based on Kolmogorov-Smirnov test results, in all cases, the magnitude of the error was greater than the error (0.05). Therefore, there is no reason to reject the zero assumption and the distribution of the data is normal.

\subsection{Confirmatory factor analysis}

3.4.1 Verifiable Factor Analysis of Human Resources Strategic Management Variable Scale

The results of the factor analysis of the human resources strategic management scale have been presented. This scale consists of 5 hidden variables and 14 visible variables. Based on the results of the measurement indices of each of the scales used at the $5 \%$ confidence level, the value of the t-value statistic is greater than 1.96 , which indicates that the observed correlations are significant. 


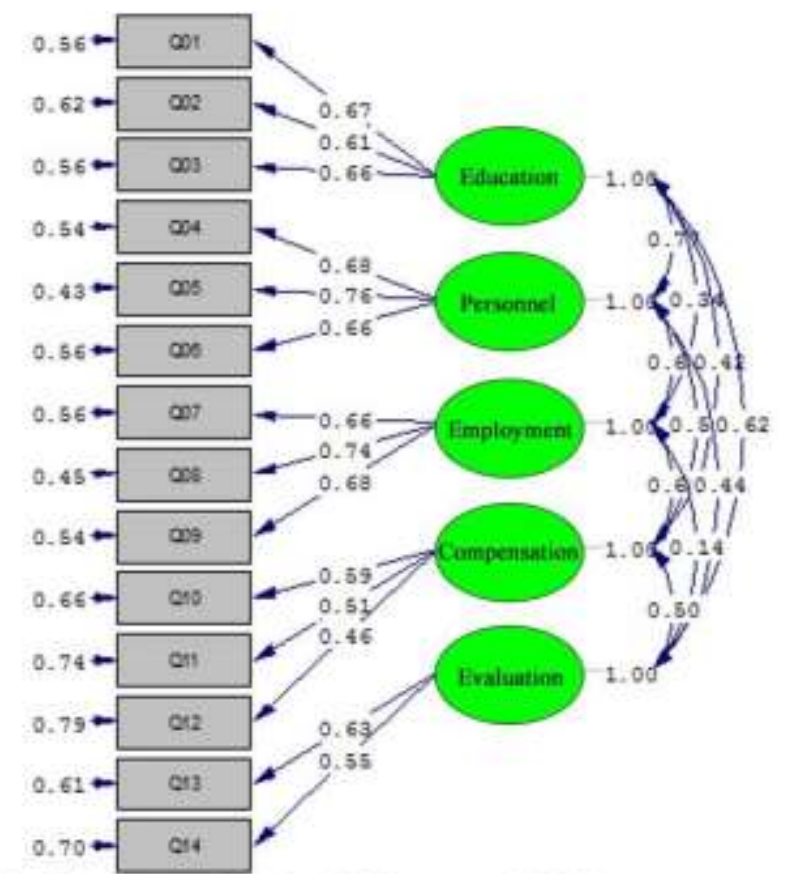

Chi-Square $=106.70$, df $=67, P-v a l u e=0.00000$, RMseA $=0.035$

Figure 1. Standard Factor Load Factor Analysis of Strategic Human Resources Management

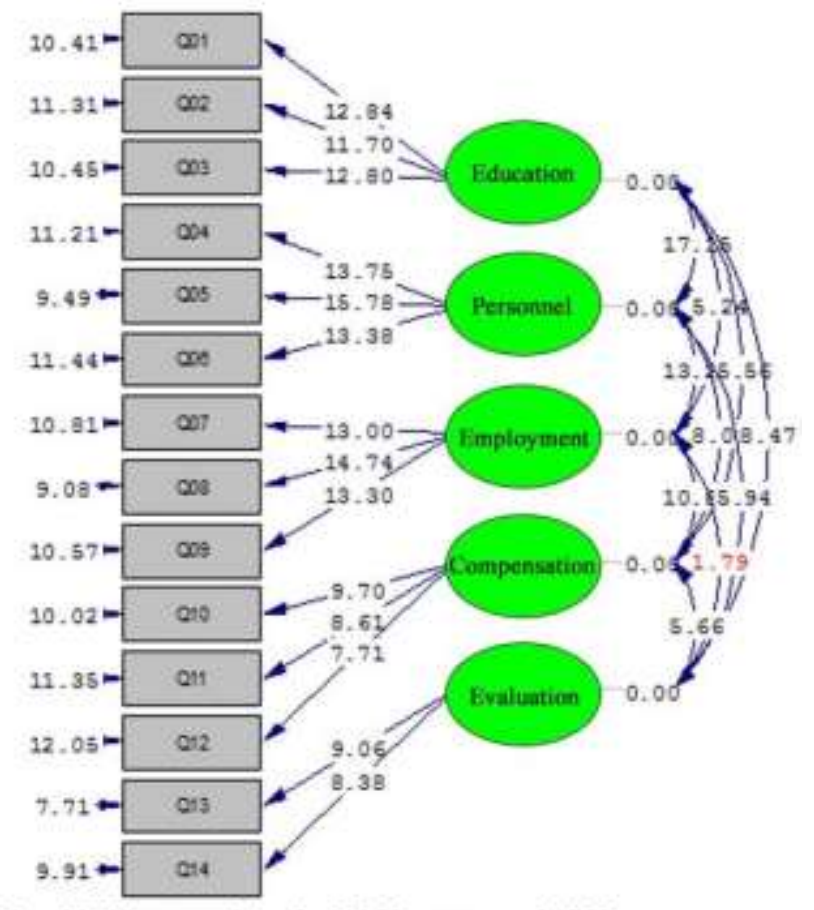

Chi-Square $=106.70$, df $=67, P$-value $=0.00000, R M S E A=0.035$

Figure 2. The value of $\mathrm{t}$ (significance) of the tangible factor analysis of strategic human resource management

The next step is goodness fitting the model. In this study, the chi distribution normal values were obtained at 59.21. Also, in the saturated model of the present study, the RMSEA index was equal to $035 / 0$, which indicates that fitting the model is desirable. 
3.4.2 Confirmatory Factor Analysis of Knowledge Management Capacity Scale

The results of Factor Analysis of Knowledge Management Capacity Scale are presented. These scales include 3 hidden variables and 10 visible variables. Based on the results of the measurement indices of each of the scales used at the $5 \%$ confidence level, the value of the t-value statistic is greater than 1.96 , which indicates that the observed correlations are significant.

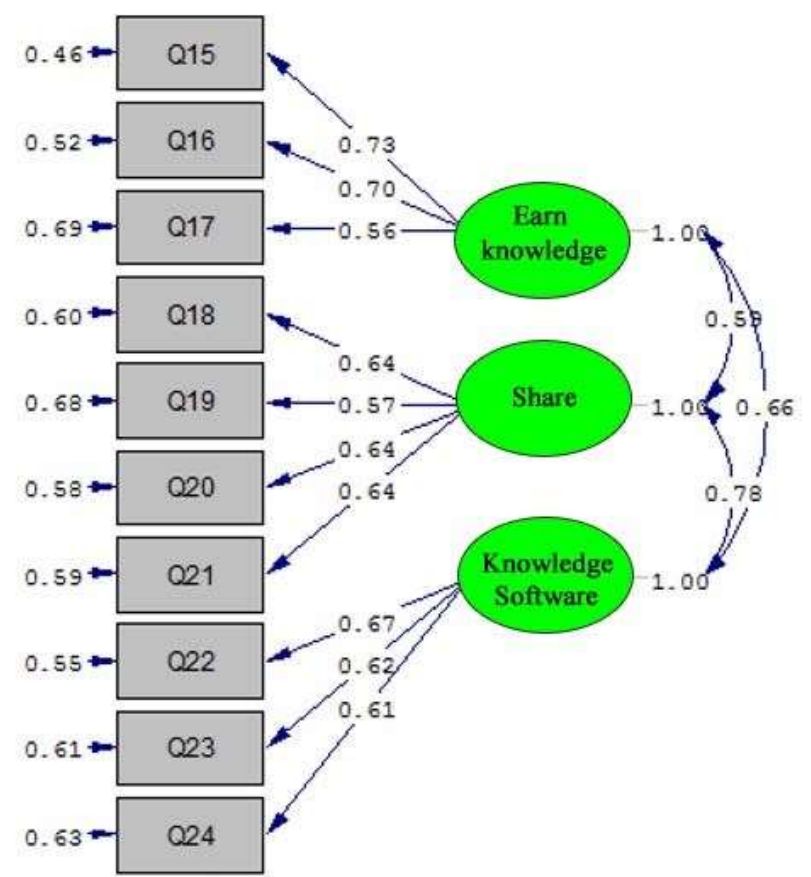

Chi-Square $=51.35, d f=32, P$-value $=0.00000, \quad \mathrm{RMSEA}=0.016$

Figure 3. Standard Factor Load. Factor Analysis. Variable Confirmation of Knowledge Management Capacity

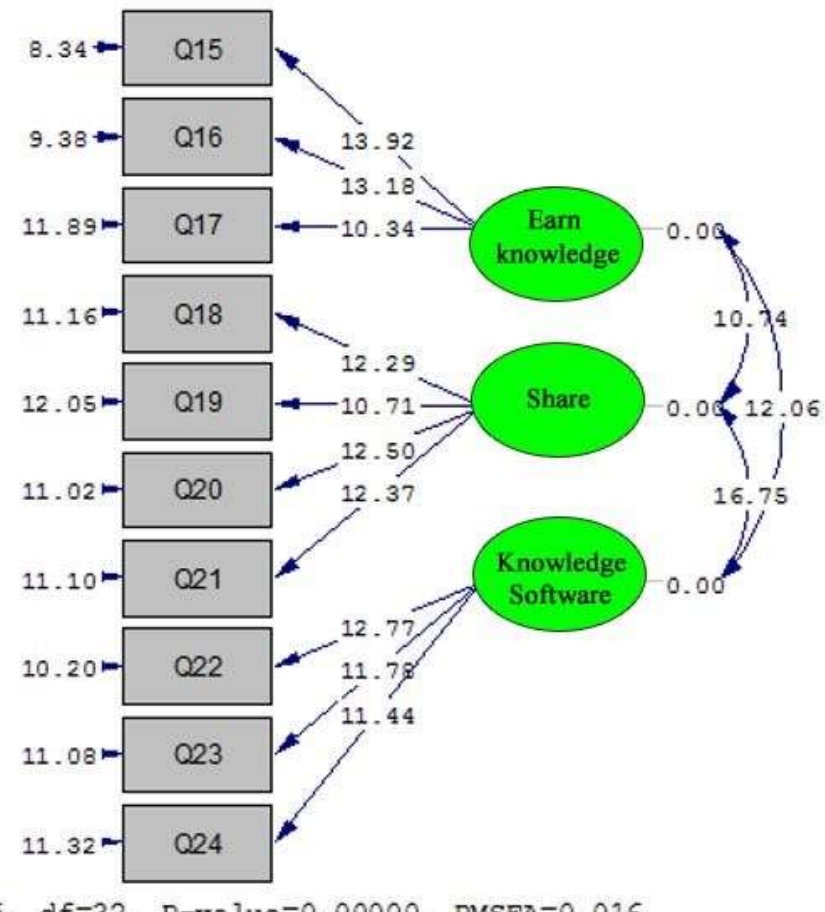

Chi-Square $=51.35, \mathrm{df}=32, \mathrm{P}-\mathrm{value}=0.00000, \mathrm{RMSEA}=0.016$

Figure 4 . The value of $\mathrm{t}$ (significance) of the confirmatory factor analysis variable of knowledge management capacity 
The next step is goodness of fitting the model. In this research, the chi distribution normalized is obtained at 1.604 . Also, in the saturated model, RMSEA index is equal to 0.016, which indicates that fitting the model is desirable.

3.4.3 Confirmatory Factor Analysis of Organizational Innovation Scale

The results of the factor analysis are presented by the organization's innovation scale. These scales include 2 hidden variables and 17 visible variables. Based on the results of the measurement indices of each of the scales used at the $5 \%$ confidence level, the value of the t-value statistic is greater than 1.96, which indicates that the observed correlations are significant.

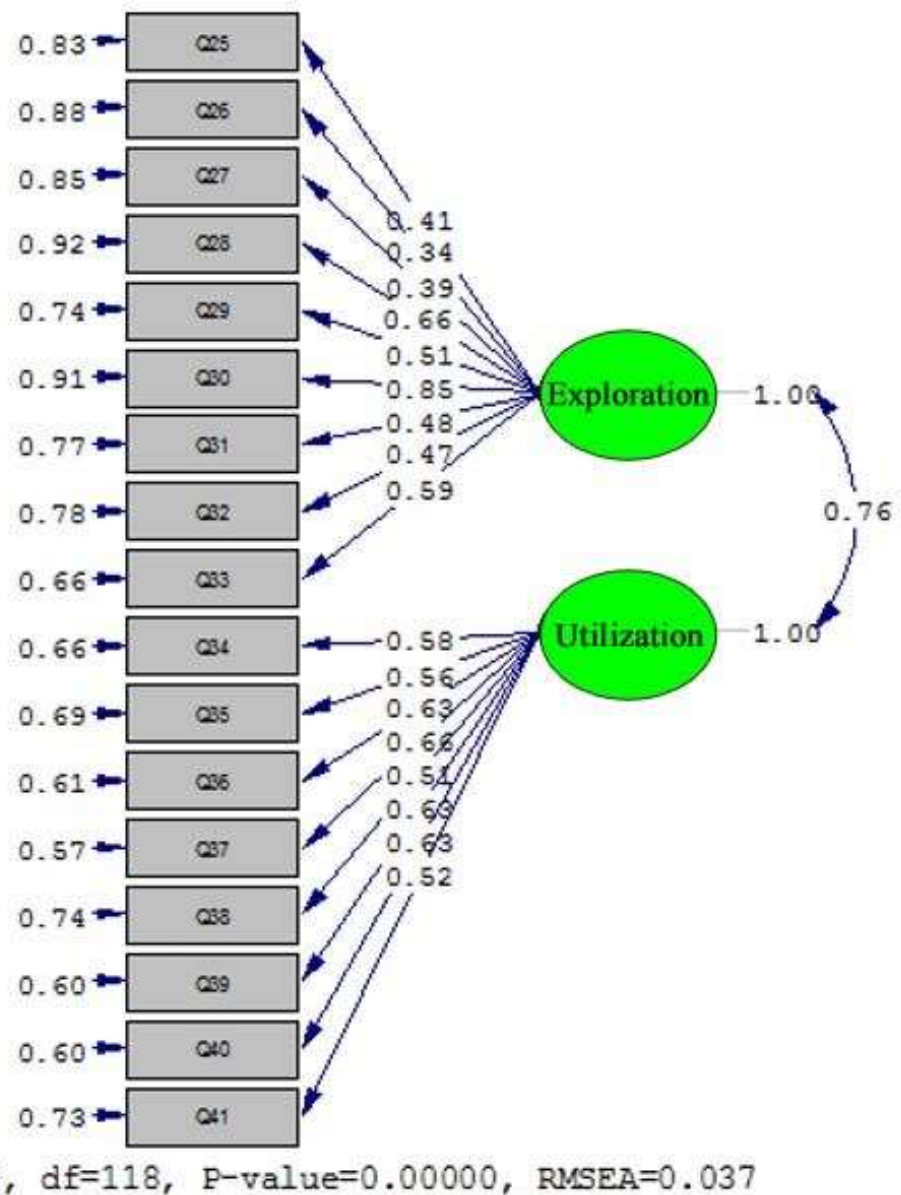

Figure 5. Standard Factor Load Factor Analysis Confirming the Variable of Organizational Innovation 


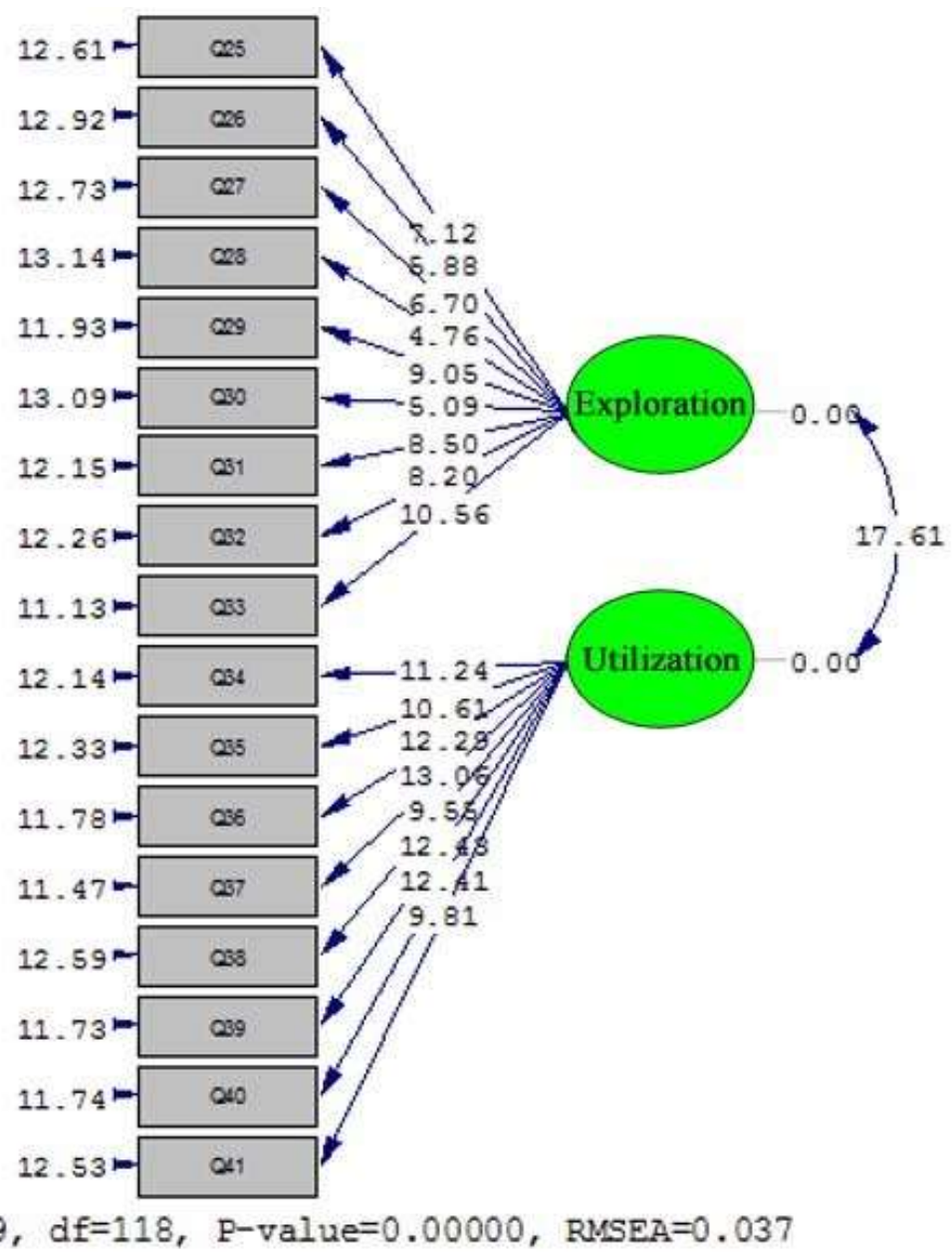

Figure 6. The value of $\mathrm{t}$ (significance) of the factor analysis confirmation variable of the organization's innovation

\subsection{Test of research hypotheses}

After verifying the structure of the research structures, structural equation modeling has been used to study the relationships between the variables. 


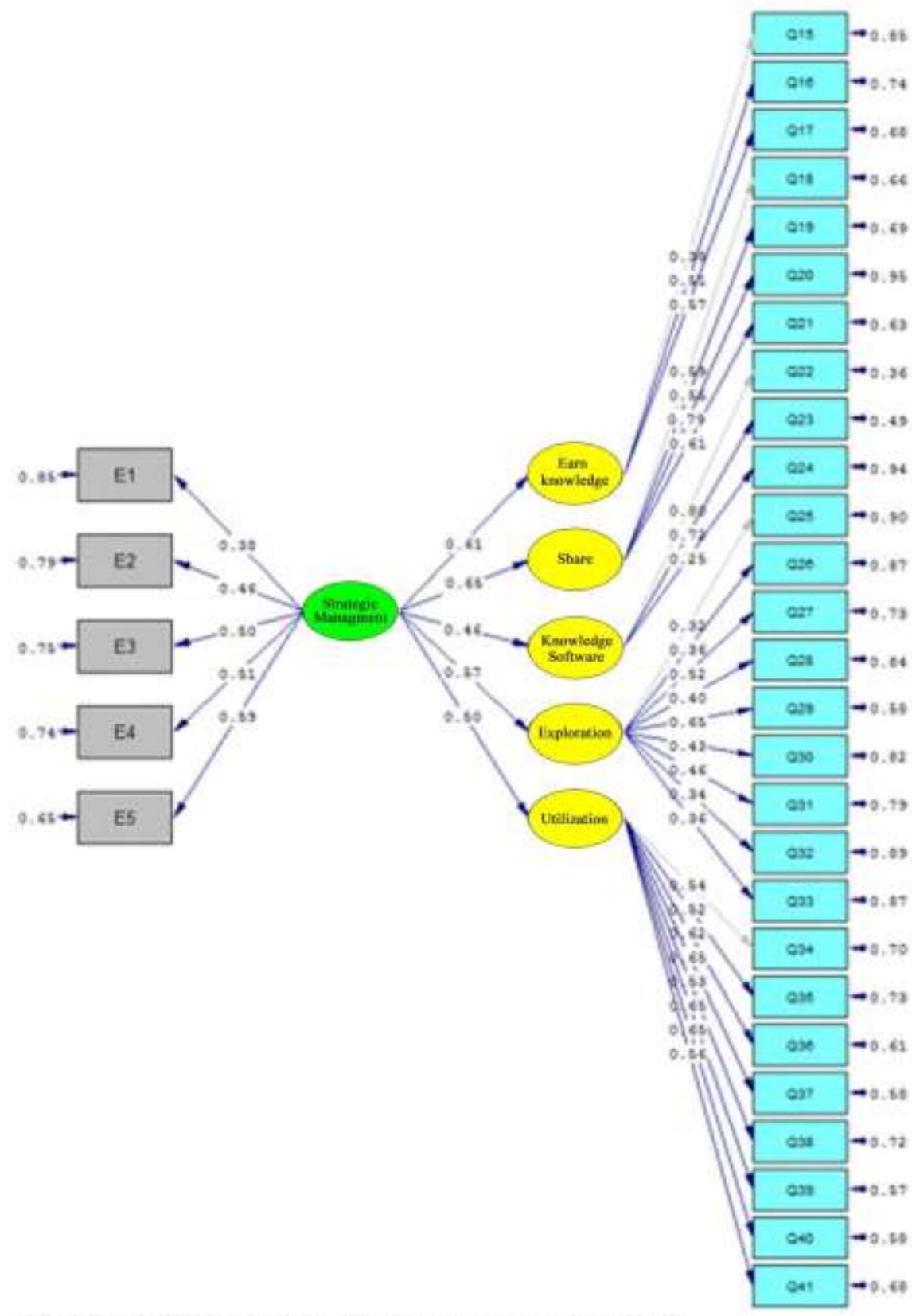

Chi-2quare=639.47, df=459, p-va1ue=0,00000, notsea=0.030

Figure 7. Proportional Strength of the Standard Test of Research Hypotheses 


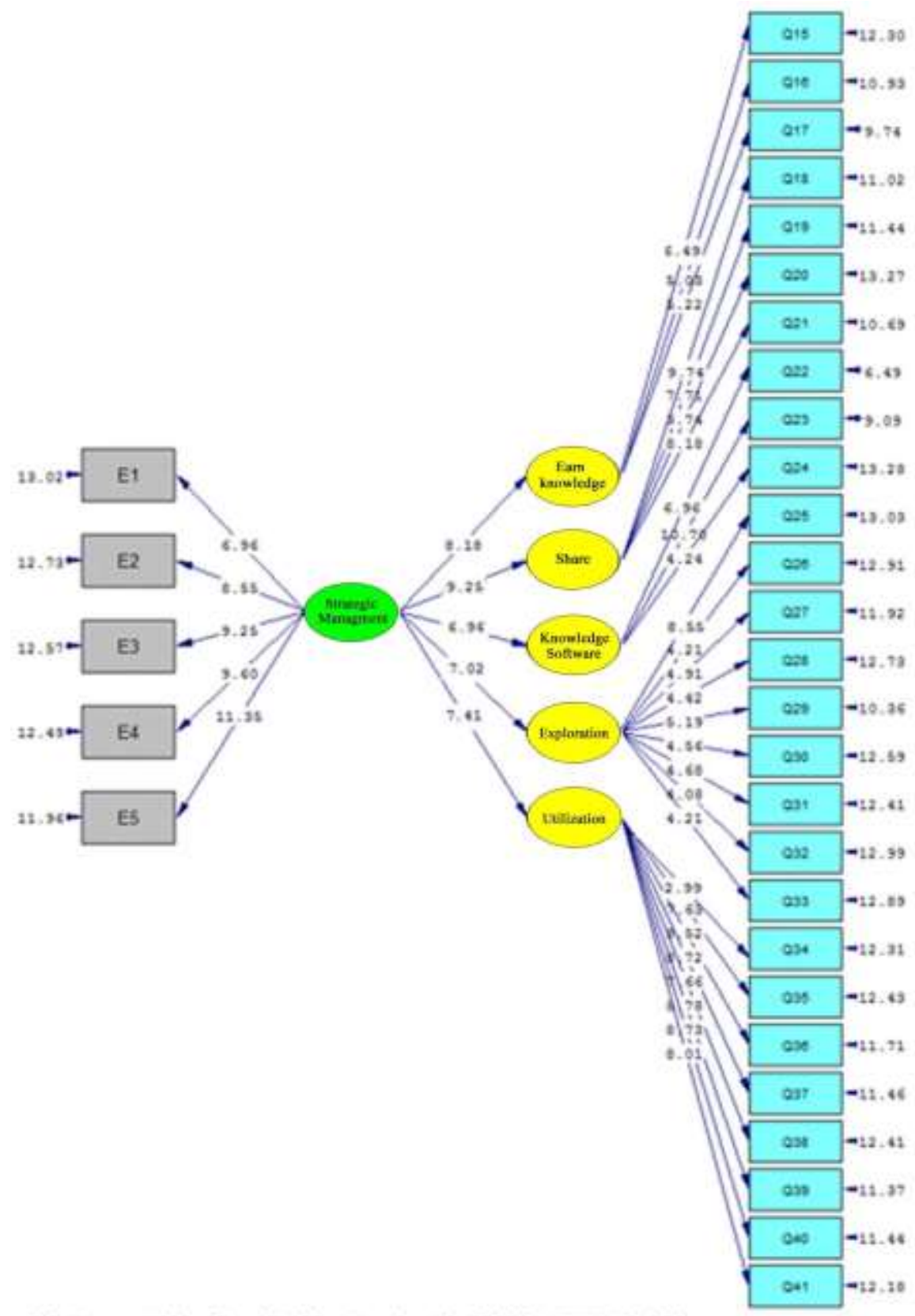

Chi-gquare"639.47, df=459, p-value=0.00000, natgra=0.030

Figure 8. T-value statistics test of research hypotheses 


\subsection{Goodness of Fit Index}

The Chi-squared Index is 1.393 and less than 2.

$\frac{\chi^{2}}{d f}=\frac{639.47}{459}=1.393$

Also, since the RMSEA index is 0.030 and less than 0.05 , the model has a good fit. Other goodness of fit Index are also well-accepted.

Table 7. Goodness of fit Index structural

\begin{tabular}{c|c|c|c|c|c|c|c}
\hline Fitness index & $\chi 2 / d f$ & RMSEA & GFI & AGFI & NFI & NNFI & IFI \\
\hline Valid values & 2 & $<0.1$ & $>0.9$ & $>0.9$ & $>0.9$ & $>0.9$ & $\mathbf{0}-\mathbf{1}$ \\
\hline Calculated values & $\mathbf{1 . 3 9 3}$ & $\mathbf{0 . 0 3 0}$ & $\mathbf{0 . 9 4}$ & $\mathbf{0 . 9 6}$ & $\mathbf{0 . 9 5}$ & $\mathbf{0 . 9 6}$ & $\mathbf{0 . 9 3}$ \\
\hline
\end{tabular}

\section{The First hypothesis:}

Strategic human resource management has an impact on knowledge acquisition.

The Load factor gained between the two variables of strategic human resource management is about gaining knowledge of 0.61. A significant value of 10.8 was obtained, which is greater than 1.96 and indicates that the correlation observed is significant. Therefore, with $95 \%$ confidence, strategic human resource management has an impact on knowledge acquisition.

Table 8. The Impact of the load factor Standard of Human Resources Strategic Management on Knowledge Acquisition

\begin{tabular}{c|c|c}
\hline Effect & load factor & Statistics T \\
\hline Strategic Human Resource Management & 0.61 & $\mathbf{8 / 1 0}$ \\
\hline
\end{tabular}

\section{The Second hypothesis:}

Strategic human resource management affects knowledge sharing.

The standardized load factor between the two variables of strategic human resource management on knowledge sharing is 0.65 . A significant value is obtained at 25/9, which is greater than 1.96 , indicating that the correlation observed is significant. Therefore, with $95 \%$ confidence, strategic human resource management affects knowledge sharing.

Table 9. The Impact of the load factor Standard of Human Resources Strategic Management on Knowledge Sharing

\begin{tabular}{c|c|c}
\hline Effect & load factor & Statistics T \\
\hline Strategic Human Resources Management on Knowledge Sharing & 0.65 & $\mathbf{9 . 2 5}$ \\
\hline
\end{tabular}

\section{The Third hypothesis:}

Strategic human resources management affects knowledge software.

The standardized load factor between the two variables of strategic human resource management on the knowledge software is 0.46 . A significant value of 6.96 is obtained, which is greater than 1.96 and indicates that the correlation observed is significant. Therefore, with $95 \%$ confidence, strategic human resource management affects knowledge software

Table 10. The Impact of the load factor Standard of Strategic Human Resources Management on Knowledge Software

\begin{tabular}{|c|c|c|}
\hline Effect & load factor & Statistics T \\
\hline Strategic Human Resource Management on Knowledge Software & 0.46 & 6.96 \\
\hline
\end{tabular}

\section{The Fourth hypothesis:}

Strategic human resource management has an impact on exploration.

The standardized load factor between the two variables of strategic human resource management have been found to be 0.57 . A meaningful value of 7.7 is obtained, which is greater than 1.96 and indicates that the correlation observed is significant. Therefore, with $95 \%$ confidence, strategic human resource management has an impact on exploration. 
Table 11. The Impact of the load factor Standard of Human Resources Strategic Management on Exploration

\begin{tabular}{|c|c|c|}
\hline Effect & load factor & Statistics T \\
\hline Strategic Human Resource Management on Exploration & 0.57 & 7.02 \\
\hline
\end{tabular}

\section{The Fifth hypothesis:}

Strategic human resource management has an impact on exploitation.

The standardized load factor between the two variables of strategic human resource management on exploitation is 0/50. A significant value of 7.14 is obtained, which is greater than 1.96 and indicates that the correlation observed is significant. Therefore, with $95 \%$ confidence, strategic human resource management has an impact on the operation.

Table 12. The Impact of the load factor Standard of Human Resources Strategic Management on Knowledge Acquisition

\begin{tabular}{|c|c|c|}
\hline Effect & load factor & Statistics T \\
\hline Strategic Human Resources Management on Operations & 0.50 & 7.14 \\
\hline
\end{tabular}

\section{The main assumptions:}

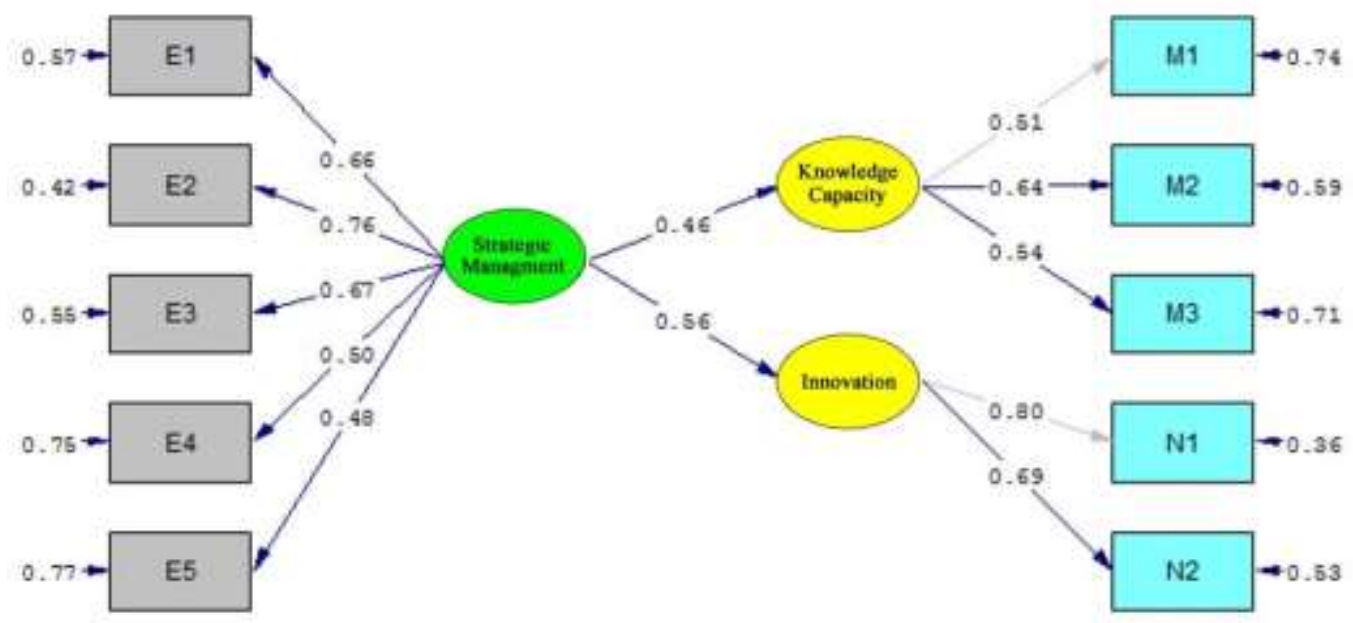

Chi-Square $=50.92$, df $=33, \mathrm{P}-\mathrm{value}=0.00000$, RUSEA $=0.027$

Figure 9. load factor Standard test of the main hypotheses of the research

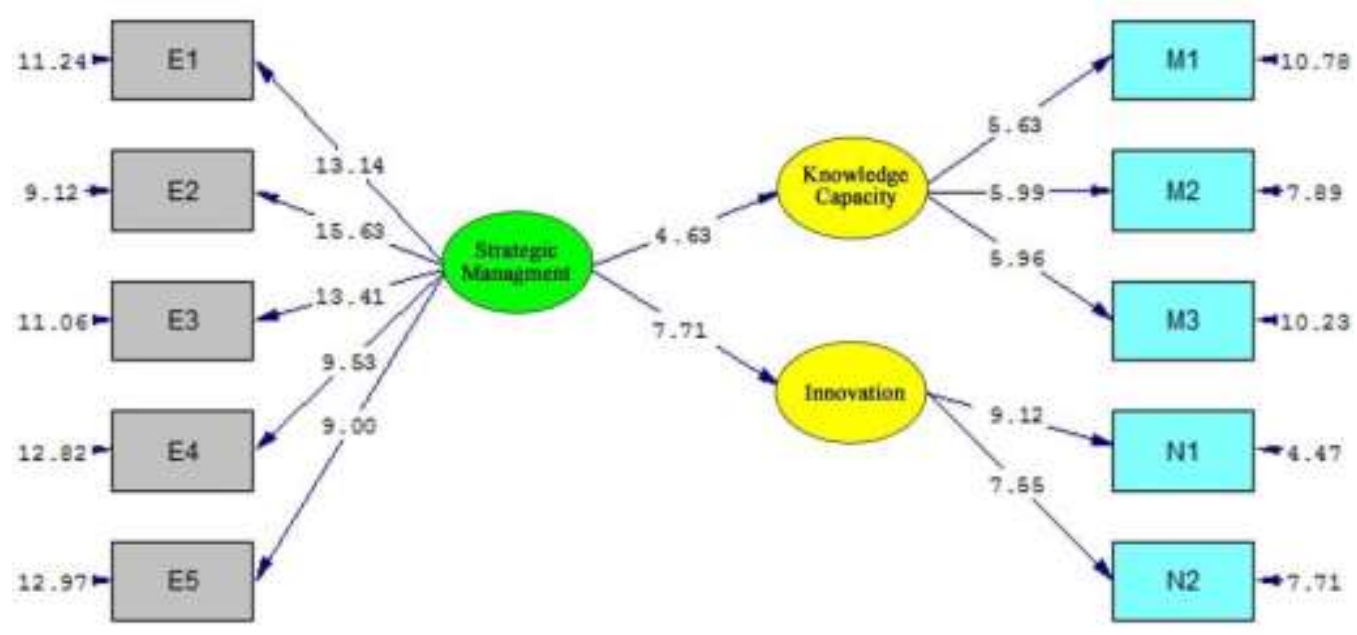

Ch1-Square $=50.92, \mathrm{df}=33, \mathrm{P}-\mathrm{value}=0.00000, \mathrm{BMSEA}=0.027$ 
Figure 10. T-value statistics test. Main research hypotheses

\section{First main hypothesis:}

Strategic human resource activities have a positive impact on organizational innovation.

The standardized load factor between the two variables of strategic human resource activities of organizations is based on organizational innovation of 0.56. A significant value of 7.71 is obtained, which is greater than 1.96 and indicates that the correlation observed is significant. Therefore, with $95 \%$ confidence, strategic human resource activities have a positive impact on organizational innovation.

Table 13. The load factor Standard of the Effects of Strategic Human Resource Activities on Organizational Innovation

\begin{tabular}{|c|c|c|}
\hline Effect & load factor & Statistics I \\
\hline $\begin{array}{c}\text { Organizational Strategic Human resource activities Activities on } \\
\text { Organizational Innovation }\end{array}$ & 0.56 & 7.71 \\
\hline
\end{tabular}

\section{Second main hypothesis:}

Organizational Human resource activities positively affects the capacity of organizational knowledge management. The standardized productivity distribution between two variables of strategic human resource activities of organizations is based on organizational knowledge management capacity of 0.46 . A significant value of 4.63 was obtained, which is greater than 1.96 and indicates that the correlation observed is significant. Therefore, with 95\% confidence, strategic human resource activities have a positive impact on organizational knowledge management capacity.

Table 14. The Impact of the load factor Standard of Strategic Human Resource Activities on Organizational Knowledge Management Capacity

\begin{tabular}{|c|c|c|}
\hline Effect & load factor & Statistics T \\
\hline $\begin{array}{c}\text { Strategic Human Resource Activities of Organizations on } \\
\text { Organizational Knowledge Management Capacity }\end{array}$ & 0.46 & 4.63 \\
\hline
\end{tabular}

\subsection{Study of the status of research variables}

The viewpoints of respondents about the importance of each of the factors and dimensions studied by the t-test have been studied. In this test, the assumption of zero (H0) is based on the fact that the variable under consideration is not in a desirable situation and the alternative assumption (H1) is also a test claim. Since the data are collected with a 5-point Likert spectrum, the mean number 3 is the midpoint of the Likert spectrum. Therefore, the statistical expression of the research hypotheses is as follows: 
$\mathrm{H} 0: \mu \leq 3$

$\mathrm{H} 1: \mu>3$

Table 15. T test results for one sample for research variables

\begin{tabular}{l|c|c|c|c|c}
\hline \multirow{2}{*}{ Research variables } & \multirow{2}{*}{ Average } & \multirow{2}{*}{ T value } & \multirow{2}{*}{$\begin{array}{c}\text { Meaningful } \\
\text { Value }\end{array}$} & \multicolumn{2}{|c}{ Confidence Interval \%95 } \\
\cline { 5 - 6 } & & & Lower limit & Upper limit \\
\hline $\begin{array}{l}\text { Strategic Management } \\
\text { of Human Resources }\end{array}$ & 3.501 & 8.481 & 0.000 & 0.382 & 0.614 \\
\hline Earn knowledge & 3.861 & 15.753 & 0.000 & 0.753 & 0.969 \\
\hline Share & 3.783 & 15.363 & 0.000 & 0.683 & 0.884 \\
\hline Knowledge Software & 3.548 & 11.080 & 0.000 & 0.451 & 0.646 \\
\hline Exploration & 3.644 & 10.836 & 0.000 & 0.527 & 0.761 \\
\hline Utilization & 3.591 & 9.771 & 0.000 & 0.472 & 0.711 \\
\hline $\begin{array}{l}\text { Knowledge } \\
\text { Management Capacity }\end{array}$ & 3.758 & 13.608 & 0.000 & 0.648 & 0.868 \\
\hline $\begin{array}{l}\text { Organizational } \\
\text { innovation }\end{array}$ & 3.444 & 8.191 & 0.000 & 0.337 & 0.550 \\
\hline
\end{tabular}

The average responses received by respondents in the strategic human resource management dimension are 3.501, which is larger than the middle limit of the Likert spectrum. A significant value of 0 is obtained, which is smaller than the error level of 0.05 , so the observed mean value is significant. The value of the $t$ statistic is 8.481 , which is larger than the critical value of 1.96. Both the upper and lower bounds of the confidence interval are somewhat greater than zero (positive) and the claim is validated. According to each of these statistical findings, 95\% confidence can be said that strategic human resource management is important.

The average score of the respondents in the field of knowledge acquisition was 3.861, which is larger than the average Likert spectrum . A significant value of 0 is obtained, which is smaller than the error level of 0.05 , so the observed mean value is significant. The value of the $t$ statistic is 15.753 , which is larger than the critical value of 1.96. Both the upper and lower bounds of the confidence interval are somewhat greater than zero (positive) and the claim is validated. According to each of these statistical findings, $95 \%$ confidence can be said: acquisition of knowledge is important.

The average response rate of the respondents was 3.783, which is larger than the average Likert range. A significant value of 0 is obtained, which is smaller than the error level of 0.05 , so the observed mean value is significant. The value of the t statistic is 15.363 , which is larger than the critical value of 1.96. Both the upper and lower bounds of the confidence interval are somewhat greater than zero (positive) and the claim is validated. According to each of these statistical findings, $95 \%$ confidence can be said: Sharing is important.

The average view of respondents in the dimension of knowledge software is 3.548, which is larger than the middle limit of the Likert spectrum. A significant value of 0 is obtained, which is smaller than the error level of 0.05 , so the observed mean value is significant. The value of the $t$ statistic is 11.08 , which is larger than the critical value of 1.96. Both the upper and lower bounds of the confidence interval are somewhat greater than zero (positive) and the claim is validated. According to each of these statistical findings, $95 \%$ confidence can be said: Knowledge software is important.

The average response rate of respondents in the dimension of exploration is 3.644, which is larger than the middle limit of the Likert spectrum. A significant value of 0 is obtained, which is smaller than the error level of 0.05 , so the observed mean value is significant. The value of $t$ is 10.836 , which is larger than the critical value of 1.96 . Both the upper and lower bounds of the confidence interval are somewhat greater than zero (positive) and the claim is validated. According to each of these statistical findings, $95 \%$ confidence can be said: exploration is important.

The average respondent's response rate was 3.591, which is larger than the average Likert spectrum. A significant value of 0 is obtained, which is smaller than the error level of 0.05 , so the observed mean value is significant. The value of the $t$ statistic is 9.771, which is larger than the critical value of 1.96. Both the upper and lower bounds of 
the confidence interval are somewhat greater than zero (positive) and the claim is validated. According to each of these statistical findings, $95 \%$ confidence can be said: exploitation is important.

The average view of respondents in the dimension of Knowledge Management capacity is 3.758, which is larger than the average Likert spectrum. A significant value of 0 is obtained, which is smaller than the error level of 0.05 , so the observed mean value is significant. The value of the $t$ statistic is 13.608 , which is larger than the critical value of 1.96. Both the upper and lower bounds of the confidence interval are somewhat greater than zero (positive) and the claim is validated. According to each of these statistical findings, $95 \%$ confidence can be said that knowledge management capacity is important.

The average view of respondents in the organization's innovation dimension was 3.444, which is larger than the middle Likert spectrum. A significant value of 0 is obtained, which is smaller than the error level of 0.05 , so the observed mean value is significant. The value of the $t$ statistic is 8.191 , which is larger than the critical value of 1.96. Both the upper and lower bounds of the confidence interval are somewhat greater than zero (positive) and the claim is validated. According to each of these statistical findings, 95\% confidence can be said: the organization's innovation is important.

\section{Conclusion}

The main hypothesis of research: Strategic human resource activities have a positive impact on organizational innovation.

The results of the main hypothesis showed that the standardized load factor between the two variables of strategic human resource activities of organizations was found to be 0.56 on organizational innovation. A significant value of 7.71 is obtained, which is greater than 1.96 and indicates that the correlation observed is significant.

Therefore, with 95\% confidence, strategic human resource activities have a positive impact on organizational innovation. The results of the main hypothesis are consistent with the research of Taleghani et al. (2017), Kamali Fahim (2016), Daudinia (2016), Razmara (2016), Ugur Yozgat et al. (2015).

In explaining this hypothesis, it can be said that strategic Human resources management is one of the most important mechanisms that fosters innovation (Esmail et al., 2010). Human resource management has implications such as commitment, proportionality, participation, and flexibility (Hoppers and Meshullam, 2010). Resource management practices are also a sustainable resource for gaining competitive advantage (Lado \& Wilson, 1994), and human resources management can help to expand organizational productivity through the development of organizational capabilities and organizational talent management (Wang et al., 2013). Most scholars also emphasize on the strategic management of human resources that the capabilities and activities of human resource management will lead to organizational innovation (Ramlal, 2006). Kamali Fahim (2016), a research on human resource management, focused on innovation through knowledge management capacities. The findings point to the fact that, although according to previous studies, human resource management capabilities have been influenced by knowledge management capacities on organizational innovation, Human resources management capabilities are not directly relevant to innovation.

Ugur Yozgat et al. (2015), a research entitled The Impact of Strategic Human resources management Impact on Organizational Innovation and Knowledge Management Capacity. The results of regression analysis emphasize that only specific activities in strategic human resources have the power to predict organizational innovation. In addition, a similar pattern was observed between strategic human resource activities and the company's knowledge management capacity. In general, our findings consider the importance of service compensation, training systems and performance evaluation as predictors of dependent variables. Shehann et al. (2013) examined the relationship between innovation and human resource development among staff in government departments in Spain. The results of this research showed that by promoting the level of innovation in the organization, human resources will grow in positive direction. Therefore, the development of innovation and creativity in the organization will lead to the development of creative staff, sensitive to environmental and innovative opportunities.

The main hypothesis of research: Organizational Human resources management positively affects the capacity of organizational knowledge management.

The results of this hypothesis show that the standardized load factor between the two variables of strategic human resource activities of organizations is based on organizational knowledge management capacity of 0.46 . A significant value of 4.63 was obtained, which is greater than 1.96 and indicates that the correlation observed is significant. Therefore, with $95 \%$ confidence, strategic human resource activities have a positive impact on 
organizational knowledge management capacity. The results of the main hypothesis of this research are consistent with the research of Ahmad Poor Dariani (2016), Kamali Fahim (2016), Razm Ara (2016), Ugur Yozgat et al. (2015).

In explaining this hypothesis it can be said Zabihi and Salehnejad (2014) in a study on the impact of HRM on the management of knowledge has concluded that companies that follow the strategic human resources management activities than companies that These activities do not perform better, and the use of human resources management actions and principles will improve the management of knowledge. Farhadi L. and Vahidian (2015) in a research entitled The Relationship between Organizational Strategies and Human Resources Management and Knowledge Management Strategies. The Imam Khomeini Relief Committee (Mazandaran Province) concluded that the strategy of the organization, human resources management with the management strategy knowledge and organizational strategy with human resource management strategy in Imam Khomeini Relief Committee in Mazandaran province have a meaningful relationship. Seyyed Naghavi and Sohrabi (2014) In a research paper titled "Patterns of KMs tailored to human resources management tasks and types of jobs, it has been concluded that there is a meaningful relationship between types of occupations and KM strategies and human resource tasks." This means that as the occupations move from central to pivotal knowledge, the KM strategy also tends to shift from coding to personalization, and subsequently changes in human resource management tasks. Garrison (1999) has a close relationship between knowledge management and human resource management. Hashemi et al. (2016), in a research on the impact of human resources management on knowledge management and organizational innovation, concluded that human resource management has an impact on organizational innovation and also strategic human resources management has an impact on knowledge management and knowledge management It also influences organizational innovation.

The first hypothesis of research: Human resource strategic management has an impact on knowledge acquisition.

The results of this hypothesis show that the standardized load factor between the two variables of strategic human resource management is about gaining knowledge of 0.61 .

A significant value of 10.8 was obtained, which is greater than 1.96 and indicates that the correlation observed is significant. Therefore, with 95\% confidence, strategic human resource management has an impact on knowledge acquisition. The results of the first hypothesis of research are consistent with the research of Ahmadpour Dariyani(2016), Kamali Fahim (1395), Razm Ara (2016), Ugur Yozgat et al. (2015).

In explaining this hypothesis, we can say that Guido Rido (2016) examines the impact of human resources management on knowledge management in private companies. The results of this study indicated that exploitation of employee involvement and participation through knowledge management is important for organizations, and human resources management is the main approach to inferring and reinforcing employee knowledge and specialized needs of the organization. Chen and Hang (2009) argued that strategic human resources actions are positively related to the capacity of knowledge management, and this also has a positive effect on innovation performance. Horticulture and Jafari (2017) in a research entitled Impact of human Resources Management on Knowledge Management Case study of the oil industry concluded that researchers' findings about the dependence of human resources management and knowledge management suggest a close relationship between employees and knowledge management.

The second hypothesis of research: Human resource strategic management affects the sharing of knowledge.

The results of this hypothesis showed that the standardized load ratio between the two variables of strategic human resource management on knowledge sharing was 0.65 . A significant value is obtained at $25 / 9$, which is greater than 1.96, indicating that the correlation observed is significant. Therefore, with $95 \%$ confidence, strategic human resource management affects knowledge sharing. The results of the second hypothesis of research are consistent with the research of Ahmadpour Dariyani (2016), Kamali Fahim (2016), Razm Ara (2016), Ugur Yozgat et al. (2015).

In explaining this research we can say that Hosseini (2017) in a research entitled The Impact of Strategic human resources management activities on Innovative Performance with the Mediating Role of Knowledge Management and Business Strategies concluded that strategic human resources management affects knowledge management Positive and meaningful. Strategic human resource management has a positive and significant impact on business strategy. The behavior of business strategy has a positive and significant impact on innovative performance. 
Knowledge management has a positive and significant impact on innovative performance. Strategic human resource management has a positive and significant impact on innovative performance. From the point of view of Nonaka and Takeuchi (1999), if the knowledge of individuals in the organization is not shared, it will not affect the growth and development of knowledge in the organization, which could lead to the development of human resources. Knowledge should be collected and organized and made available to the members of the organization benefiting from it.

\section{The third hypothesis of research: Human resource strategic management affects knowledge software.}

The results of this hypothesis show that the standardized load factor between the two variables of strategic human resource management on the knowledge software is 46.4. A significant value of 6.96 is obtained, which is greater than 1.96 and indicates that the correlation observed is significant. Therefore, with $95 \%$ confidence, strategic human resource management affects knowledge software. The results of the third hypothesis of research are consistent with the research of Ahmad Poor Dariyani (2016), Kamali Fahim (2016), Razm Ara (2016), Ugur Yozgat et al. (2015).

In explaining this hypothesis it can be said that the knowledge management system, as an efficiency tool, can be coordinated with other actions that are performed to improve the performance and efficiency of the organization. The secret is the organization's success in productivity and knowledge management. In both of them, human resources play an important role. Today, managers are trying to extract knowledge from the members of the organization through knowledge management, and share it among all individuals so that the knowledge stored in the system becomes a permanent usable resource and a sustainable competitive advantage (Davenport, 1998). Major human resources management tools are aimed at improving the level of knowledge management in the organization. For example, performance appraisal as a human resources management tool is the basis for payment and promotion in the organization. Therefore, it has a central role in creating functional and behavioral changes in employees. In many organizations, organizational structure is as such In order to facilitate activities and improve the level of performance, a bunch of responsibilities and activities are carried out in the form of an organizational unit, which, within the scope of their tasks, are independent in terms of plans, activities, decisions, and even financial resources. Act. These independent units can be created in different forms (Saeed Hossein Rafiee, 2009).

The main task of human resources management is to monitor, measure and interfere in the structure of the visualization, distribution, and application of employee knowledge, and also the task of manpower management can also help the organization in the production and maintenance of capability. (Hojat Haydarzadeh Moghaddam and Solmaz Rajabzadeh, 2009).

\section{The fourth hypothesis of research: Human resource strategic management affects knowledge discovery.}

The results of this hypothesis show that the standardized load factor between the two variables of strategic human resource management is about 57\%. A meaningful value of 7.7 is obtained, which is greater than 1.96 and indicates that the correlation observed is significant. Therefore, with $95 \%$ confidence, strategic human resource management has an impact on exploration. The results of the fourth hypothesis of research are consistent with the research of Ahmadpour Dariyani (2016), Kamali Fahim (2016), Razm Ara (2016), Ugur Yozgat et al. (2015).

In explaining this hypothesis we can say that the process of information acquisition is realized with two different perspectives. The first point is the acquisition and acquisition of knowledge management, which includes exploitation through available knowledge. The company's critical information is taken from the surrounding environment, including customers, competitors, suppliers, and other individuals that affect the company's operations. The second perspective is the acquisition and acquisition of knowledge management, which involves discovering retrieval by sharing and combining knowledge. The ideas and information that change the way and how to do the work are used by the company. The company has the opportunity to Combine the new knowledge and create new knowledge. Collective information generation is done by instilling employee knowledge and sharing information. When sharing and sharing knowledge is desirable, it is possible for individuals to create collective learning. And benefit from the exchange of knowledge and resources. The use of knowledge, the focal point for the mediating process From the perspective of knowledge, the value of individual and organizational knowledge mainly depends on the application and nature of knowledge. An effective application of knowledge makes it possible for individuals to make minor mistakes and improve their efficiency and reduce redundancy. Allameh and Gani (2015) in a research entitled Human Resources Management and KM, concluded that knowledge management strategy was influenced by corporate strategy and human resources management strategy. Two knowledge management strategies have been identified. Extraction strategy and extraction strategy exploration strategy emphasizes the accumulation of technical knowledge and skills and the distribution of 
knowledge through information technology while the exploratory strategy of knowledge gained through the transfer of tacit knowledge through interactions and increased innovation and learning Emphasizes.

\section{The fifth hypothesis of research: Strategic human resource management has an impact on exploitation.}

The results of this hypothesis showed that the standardized load factor between the two variables of strategic human resource management on exploitation is 50\%. A significant value of 7.14 is obtained, which is greater than 1.96 and indicates that the correlation observed is significant. Therefore, with 95\% confidence, strategic human resource management has an impact on the operation. The results of the fifth hypothesis are consistent with the research by Ahmadpour Dariyani (2016), Kamali Fahim (2016), Razm Ara (2016), Ugur Yozgat et al. (2015).

In explaining this hypothesis, it can be said that exploitation means using innovative methods in an organization and trying to innovate an organization (Alonen et al., 2008). Rezaei Rad et al., In a research on the impact of strategic human resources management functions on performance performance, emphasizing on the role of the interface between knowledge management capacity in the Besat Hospital of Hamedan, concluded that the strategic human resources responsibilities of knowledge management capacity have a decisive impact on the performance of employees. Therefore, success in their correct implementation will be synergistic with the promotion of performance enhancements. Khalilvand et al. (2016) in a research study on the impact of strategic human resource management on organizational innovation with the role of mediation of knowledge management (all employees of Elam University's non-governmental universities) concluded that the dimensions of strategic human resource management on the organizational innovation of the university Non-governmental organizations in Elam have a significant effect, and strategic talent management has a significant effect on knowledge management in Elam universities. Knowledge management has a significant role in the organizational innovation of non-governmental universities in Elam effect.

Layeghi (2017) concluded in a research on the impact of strategic human resources management on innovation and knowledge management that there is a significant relationship between strategic human resources management and innovation and knowledge management.

\section{Reference}

Taleghani et al. (2017), Investigating the Impact of Human Resources Management on Improving Organizational Performance among Tehran University Employees, Public Administration, No. 1, pp. 14-1.

Navabi, Raazieh (2017), The Effect of Knowledge Based Culture with Knowledge Management Approach on Organizational Performance of Masters, Allameh Tabatabaei University, Faculty of Education and Psychology.

Davodinia, Daro. (2016), The Impact of Involving Employees on Organizational Performance through Innovation: The Role of Human Resources Management, Masters, Higher Education and Research, Management and Planning.

Razam Ara, Setareh (2016), Presentation of Human Resources Management Model Based on Knowledge Management with Emphasis on Innovative Performance in Major Companies, MS, Payame Noor University of Tehran, Faculty of Industrial Engineering.

Hanifi, Saba (2016), Effect of Leadership Style on Organizational Innovation with Mediating Knowledge Management, Khatam University, School of Accounting and Management.

Ahmadpour Dariani, Mahmoud (2016), Identifying the Success Factors of Human Resource Management in Small Business, Entrepreneurship Development, No. 1, pp. 20-1.

Amin Moghaddam, Ali; Sotoudeh Math, Maryam. (2015), Presentation of a Model for the Development of Knowledge Management in Research Organizations with the Approach of Effective Use of Information and Communication Technology, Fifth Conference of Research and Development Centers of Industries and Mines, Tehran

Worlds of Ramadan. (2015). Investigating the Relationship between Intellectual Capital with Innovation and Creativity of Human Resources in Organizations, Initiatives and Creativity in Humanities: Summer, Volume 5 , Issue 1. 
Hamidizadeh et al, (2014) "Investigating the Effect of Social Capital Components on Organizational Innovation (Case: Telecommunications General Office of Qom Province)”, Social Capital Management Journal.

Moshabaki, Asghar, Bastam, Hadi, Deh Yadegari, Saeed (2011), promotion of organizational performance through purposeful organizational forgetting.

Yozgat, U., Findıklı, M., Rofcanin, Y, (2015). Examining Organizational Innovation and Knowledge Management Capacity The Central Role of Strategic Human Resources Practices (SHRPs), Procedia - Social and Behavioral Sciences 181 ( 2015 ) 377 - 387.

Risseeuw, P., Masurel, E, (2014.). The role of planning in small firms: empirical evidence from a service industry, Small Business Economics 6: 313-322.

Birasnav, M. (2014), Knowledge management and organizational performance in the service industry: the role of transformational leadership beyond the effects of transactional leadership, Journal of Business Research, Vol. 67 No. 8, pp. 1622-1629.

Lee, G, G, and Bai, R. J, (2013), Organizational mechanism for successful IS/IT strategic planning in the digital era, Management Decision, 41(1): 32- 42.

Oke, A., D. I. Prajogo, J. Jayaram. 2013. Strengthening the innovation chain: The role of internal innovation climate and strategic relationships with supply chain partners. Journal of Supply Chain Management, 49(4), 43-58.

Short, J, C and Ketchen, D.J and Palmer, T.B, (2012). The role of sampling in strategic management research on performance, a two-study analysis Journal of Management 28, PP. 363-385.

Wagner, S.M. 2012. Tapping supplier innovation. Journal of Supply Chain Management 48(2), 37-52.

Schiele, H. 2012. Accessing supplier innovation by being their preferred customer. Research- Technology Management, 55(1), 44-50.

Hensey, M. (2011). Essential Success Factors for Strategic Planning, Journal of Management in Engineering, 7(2): $77-167$

Harpez, I \& Meshoulam, I. (2010). The Meaning of Work, Employment Relation, and-Strategic Human Resource Management in Israel. Human Resource Management.

Nonaka, I and Takeuchi, H (1995), “The knowledge creating company, New York”: Oxford Universit 